\title{
THE RELATIVE EFFECT OF AGE IN INTERNATIONAL FOOTBALL: EUROPE VS SOUTH AMERICA
}

\author{
José María Yagüe ${ }^{1}$; José María Izquierdo ${ }^{1}$; Álvaro Muñoz ${ }^{1}$; \\ Joaquín Sánchez ${ }^{2}$; Juan Carlos Redondo ${ }^{1}$
}

1. Department of Movement and Sport Sciences, University of Leon, Spain.

2. European University of Madrid, Spain

\begin{abstract}
The concept of relative age effect refers to the consequences of the physical and psychological differences that may exist between those born earlier or later within the same calendar year. The objective of the present study was to examine this phenomenon in international professional football, identifying the influences of the continent. The sample comprised 6448 subjects from 225 teams (115 UEFA and 110 CONMEBOL) from the professional football Leagues (PFL). Statistical analysis was based on the Chi-squared $\left(X^{2}\right)$ test followed by the odds ratios (OR) and $95 \%$ confidence intervals estimation. The main results show higher RAE in the CONMEBOL leagues (OR $=2.23)$ than in the UEFA leagues $(O R=1.95)$. In addition, in all leagues analysed, except in the Premier League of England there was an over-representation of individuals born in the first few months of the year. We can conclude that the relative age effect is consistent and exists in international football.
\end{abstract}

Keywords: birth quarter, leagues, talent identification, RAE

\section{EFECTO DE LA EDAD RELATIVA EN EL FÚTBOL INTERNACIONAL: EUROPA VS SUDAMÉRICA}

\begin{abstract}
RESUMEN
El concepto de efecto de edad relativa se refiere a las consecuencias de las diferencias físicas y psicológicas que pueden existir entre los nacidos antes o después dentro del mismo año calendario. El objetivo del presente estudio fue examinar este fenómeno en el fútbol profesional internacional, identificando las influencias del continente. La muestra comprendió 6448 sujetos de 225 equipos (115 UEFA y 110 CONMEBOL) de las Ligas de fútbol profesional (PFL). El análisis estadístico se basó en la prueba de Chi-cuadrado $\left(\mathrm{X}^{2}\right)$ seguido de los odds ratios (OR) y la estimación de intervalos de confianza del 95\%. Los principales resultados muestran un RAE más alto en las ligas CONMEBOL $(O R=2,23)$ que en las ligas de la UEFA $(O R=1,95)$. Además, en todas las ligas analizadas, excepto en la Premier League de Inglaterra, hubo una sobrerrepresentación de las personas nacidas en los primeros meses del año. Podemos concluir que el efecto de la edad relativa es consistente y existe en el fútbol internacional.
\end{abstract}

Palabras clave: trimestre de nacimiento, ligas, selección de talento, RAE

Correspondence:

Juan Carlos Redondo

Department of Movement and Sport Sciences, University of Leon, Spain.

jc.castan@unileon.es

Submitted: 13/02/2020

Accepted: 01/06/2020 


\section{INTRODUCTION}

Subjects' grouping by age is common in certain areas of our society such as school, sports or clinical psychology (Gutiérrez, 2013). In so-called grassroots football competitions, players are grouped according to their chronological age into two or three years in length categories. In 1997, the International Football Federation (FIFA) set a cut-off date from January the $1^{\text {st, }}$, based on our 12month calendar. This decision, which aims to ensure, theoretically, maximum equal opportunity for athletes in the varied fields of competition (Musch y Grondin, 2001), has the weakness of ignoring the mature age (Helsen, Van Winckel, y Williams, 2005; Malina, Bouchard, y Bar-Or, 2004). This maturation and growth rate is different in every subject, and, therefore, it can be assumed that it has a significant incidence on the sports career of the subjects (TorresUnda et al., 2013), with a negative effect on those born in the last months of the year. And, on the contrary, providing greater success' chances to those born in the first months of the year (Bell, Sykes, y Vidal, 2009), and greater possibilities of reaching high level (Delorme, Boiché, y Raspaud, 2010). The differences of up to 12 months, caused in these cluster policies is what is known as relative age, and their consequences set the so-called Relative Age Effect-RAE (Campbell, 2013; Gutiérrez et al., 2010).

Barnsley, Thompson \& Legault (1992) were among the first authors to study the RAE in the 1990s, encompassing players from around the world. In their study they analysed data from players under 20 (U20) and under 17 of the 1990 Football World Cup. Few years later, Williams (2010) studied the effect of the relative age analysing different geographic zones, with players U17 that participated in the U17 Football World Cup from 1997 to 2007, proving that the RAE is present in all the geographic areas determined by FIFA, with the exception of Africa where it was observed the inverse effect in terms of number of players per quarter.

Padrón-Cabo, et al. (2016), in their study of different professional leagues around the world, confirm the existence of RAE in most of them except in the English Premier League. This could be due to the fact that the English Football Association (FA) changed the cut-off date for the division of categories, replacing January 1 as the first day of the cut-off date with September 1, thus copying the cut-off date to the English school system (González-Víllora, PastorVicedo, y Cordente, 2015). Padrón-Cabo et al. (2016) also demonstrated the presence of RAE in leagues of different continents, such as the first divisions of Mexico, Australia, Russia, Belgium and Ukraine, as well as the second divisions of the countries of Spain, France, Italy, Germany, Holland, Portugal, Russia, Belgium and Ukraine. But the representativeness of the sample between continents was not very large. This study, raises concerns about the comparison of the existence of the RAE in professional leagues on different 
continents. Práxedes et al. (2019) confirmed a greater representation of players born in the first half of the year in the structure of Spanish male football, both those players born in Spain and those who have come from another countries, which indicates that this phenomenon, its causes and consequences, could spread across more countries (Prieto, Pastor, Serra, y González, 2015). And for this, we believe that it is necessary to obtain a wide sample that allows to differentiate them in a significant way since, as far as we have been able to study, the existing studies have little representative samples.

Therefore, the objective of this study was to verify the existence of the RAE among professional league players from different continents such as European leagues belonging to the Union of European Football Associations (UEFA) and South American leagues belonging to the South American Football Confederation (CONMEBOL), by selecting a representative sample in order to study the existence of differences in the RAE among these professional footballers from both continents.

\section{METHOD}

In order to observe the impact of the RAE on international football, the birth dates of all the players in the six major European and South American football leagues, at the beginning of the season 2016/2017 have been analysed. These six main European and South American leagues are grouped within the Union of European Football Associations (UEFA) and the South American Football Confederation (CONMEBOL) respectively. To develop our study, data were collected manually from a public-accessed football statistic website named www.transfermarkt.com, which is considered a primary source of data in the football industry (Peeters, 2018). The study was carried out in accordance with the principles established by the Helsinki Declaration and was approved by the ethics committee of the University of León.

The selection process for these leagues has been carried out through the "The strongest league in the world 2015" list published by the IFFHS (International Federation of Football History and Statistics), which is the latest published list of the strongest leagues in the world of football. This list was published in January 2016. According to this list were selected the first six European leagues that are part of UEFA and the first six South American football leagues that are part of CONMEBOL.

\section{Participants}

Data from a total of 6448 football players were collected in a database created ad hoc for the present study. Table 1 shows the final distribution of the number of players according to their category belonging: UEFA (EU; $n=3051$ ), CONMEBOL (CO; $n=3397$ ), and the distribution of the corresponding 225 teams 
in each category. They were divided according to their date of birth under the pertaining quarter: Q1 (January, February and March), Q2 (April, May and June), Q3 (July, August and September), and Q4 (October, November and December). They were also distributed in accordance with the country of competition.

\section{Statistical analysis}

Data analysis was carried out using the Statistical Package for Social Sciences (SPSS 24.0). To evaluate the existence of differences between the observed and expected birth date distributions, the Chi-square test $\left(X^{2}\right)$ was used depending on the categories under study, assuming a similar distribution of the year's quartiles. In those cases, in which this test revealed the existence of statistically significant differences, the odds ratio (OR) and the $95 \%$ confidence interval (CI) were calculated. The distribution of those born in the first quarter was always used as reference data, as proposed by (Campos, Campos, Pellegrinotti, y Gómez, 2017; Cobley, Schorer, y Baker, 2008). To assess the relevance of groups differences, the effect size (ES) of the chi-square significance was calculated, defined as the square root of the quotient between the value of chi-square statistic $(\chi 2)$ and the number of cases (Albuquerque et al., 2013). Cohen (1988) suggests that values of ES of 0.10 represent a small effect, the value of 0.30 a medium effect and the value of 0.50 a large effect. In the case of the $\mathrm{OR}$, being a quotient, confidence intervals containing the value of 1 indicate no statistical significance (Szumilas, 2010). The higher the odds ratio, the greater the risk of players being born in the assessed quarter compared to the reference quarter. Kolmogorov Smirnov test was used to verify the normality of the variables and the level of significance was $\mathrm{p}<0.05$.

\section{RESULTS}

Kolmogorov Smirnov's test indicated that all variables were distributed normally ( $p>0.05$ ). In Table 2 we can see the distributions of births per quarter for the five subgroups. Chi-square analyses (X2) revealed that the date of birth distributions of all groups of football players differed significantly ( $\mathrm{p}<$ 0.05), except for the English league ( $p=0.05)$. Figure 1 shows that Q1 and Q2 are over-represented in the two categories studied. 


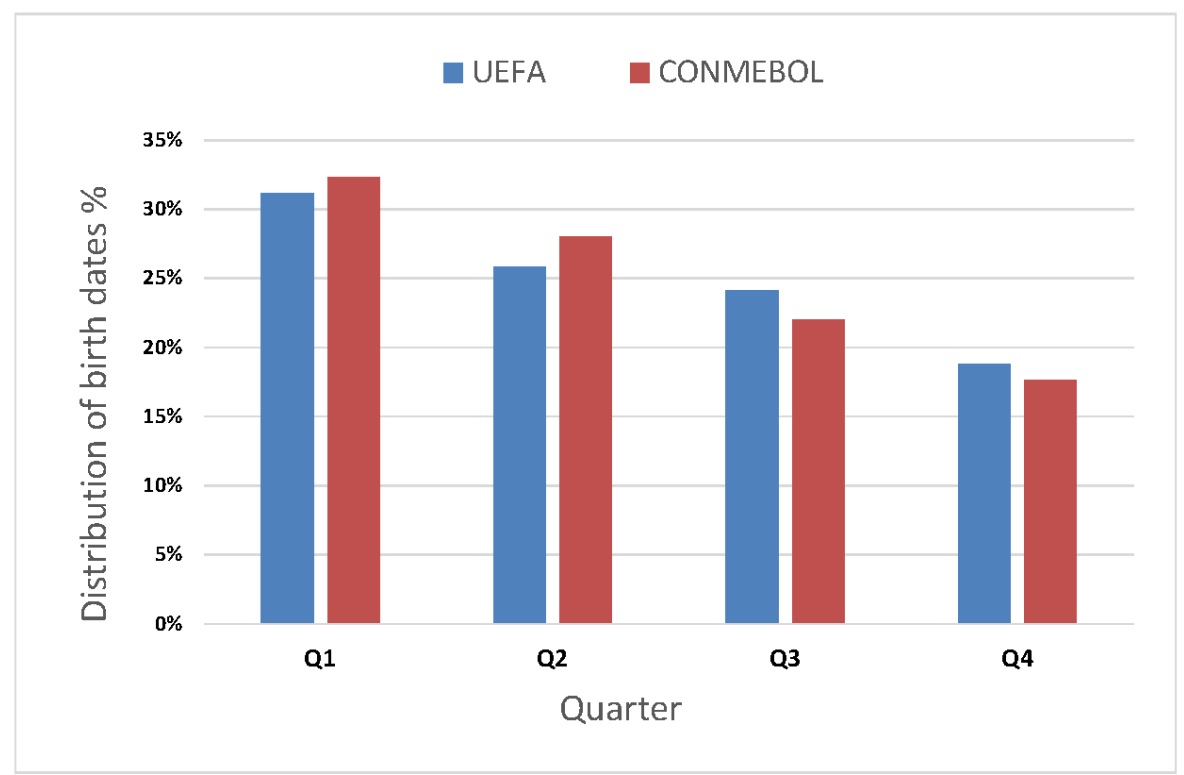

FIGURE 1: Distribution of the dates of birth by quarters, of both categories' players.

TABLE 1

Number (fr) of players analyzed by teams.

\begin{tabular}{|c|c|c|c|c|}
\hline Category & Country & League & № Teams & № Players \\
\hline \multirow{6}{*}{$\begin{array}{c}\text { UEFA } \\
\text { (EUROPE) }\end{array}$} & ENGLAND & Premier league & 19 & 522 \\
\hline & FRANCE & Ligue 1 & 20 & 534 \\
\hline & SPAIN & League Santander & 20 & 481 \\
\hline & GERMANY & Bundesliga & 18 & 514 \\
\hline & ITALY & Serie A & 20 & 473 \\
\hline & PORTUGAL & Primeira Liga & 18 & 519 \\
\hline \multirow{7}{*}{$\begin{array}{c}\text { CONMEBOL } \\
\text { (SOUTH-AMERICA) }\end{array}$} & ARGENTINA & First division & 30 & 904 \\
\hline & BRAZIL & Serie A & 20 & 712 \\
\hline & COLOMBIA & Primera A & 20 & 586 \\
\hline & CHILE & First division & 16 & 439 \\
\hline & ECUADOR & Championship 2016 & 12 & 346 \\
\hline & PARAGUAY & First division & 12 & 384 \\
\hline & & TOTAL & 225 & 6.414 \\
\hline
\end{tabular}

In addition, Table 2 also shows the results of the odds ratio and $95 \% \mathrm{CI}$, according to the category (UEFA or CONMEBOL) and the competition country. Analyzing the results obtained by quarters, we can observe that the highest odds ratio are found when comparing Q1 and Q4, with values that decrease as we compare the first quarter with the closest (Q3 and Q2). Respecting to categories, analysing the results obtained by quarters, we can observe that the highest value of odds ratio corresponds to the comparison Q1-Q4, in the CONMEBOL category $\left(\chi^{2}=169,89 ; p<0.001 ; E S=0.22\right)$. indicates a value of 
2.23 that implies that, in this category, the probability (generically called risk) of being part of the Professional Football League (PFL) is more than twice greater, being born in the first quarter (Q1) than being born in the fourth quarter (Q4).

Focused on leagues, Table 2 shows that chi-square analyses $\left(\chi^{2}\right)$ revealed that the league with the greatest significant differences (OR $=2.85, \mathrm{Q} 1-\mathrm{Q} 4)$ in date of birth distributions, is the Brazilian league $\left(\chi^{2}=58.18\right.$; $\mathrm{p}<0.001$; $\mathrm{ES}=$ $0.29)$. In the Italian league $\left(\chi^{2}=30.94 ; p<0.001\right.$; $\left.E S=0.26\right)$-UEFA category-, the greatest significant differences were observed in the comparison Q1-Q4, with an $\mathrm{OR}=2.69$. 
TABLE 2

Quarters of birth distribution (frequency, \%) according to the category and players' competition country ( $\mathrm{n}=6448)$.

\begin{tabular}{|c|c|c|c|c|c|c|c|c|c|c|c|c|}
\hline & \multicolumn{9}{|c|}{ QUARTER } & \multicolumn{3}{|c|}{ Odds Ratio (CI 95\%) } \\
\hline & Q1 & Q2 & Q3 & Q4 & Total & & & & & & & \\
\hline & $\mathrm{fr}$ & $\mathrm{fr}$ & $\mathrm{fr}$ & $\mathrm{fr}$ & $\mathrm{fr}$ & $\mathrm{X} 2$ & $\mathrm{gl}$ & $\mathrm{p}$ & ES & Q1-Q4 & Q2-Q4 & Q3-Q4 \\
\hline & $\%$ & $\%$ & $\%$ & $\%$ & $\%$ & & & & & & & \\
\hline \multirow{2}{*}{ TOTAL } & 2049 & 1740 & 1486 & 1173 & 6448 & \multirow{2}{*}{257.37} & \multirow{2}{*}{3} & \multirow{2}{*}{$<0.001$} & \multirow{2}{*}{0.20} & 1.49 & 1.38 & 1.18 \\
\hline & 31.78 & 26.99 & 23.05 & 18.19 & 100.00 & & & & & $(1.60-1.39)$ & $(1.49-1.27)$ & $(1.26-1.10)$ \\
\hline \multirow{2}{*}{ UEFA } & 951 & 789 & 737 & 574 & 3051 & \multirow{2}{*}{94.94} & \multirow{2}{*}{3} & \multirow{2}{*}{$<0.001$} & \multirow{2}{*}{0.18} & 1.95 & 1.51 & 1.37 \\
\hline & 31.17 & 25.86 & 24.16 & 18.81 & 100.00 & & & & & $(2.17-1.76)$ & $(1.68-1.35)$ & $(1.52-1.24)$ \\
\hline \multirow{2}{*}{ CONMEBOL } & 1098 & 951 & 749 & 599 & 3397 & \multirow{2}{*}{169.89} & \multirow{2}{*}{3} & \multirow{2}{*}{$<0.001$} & \multirow{2}{*}{0.22} & 2.23 & 1.82 & 1.32 \\
\hline & 32.32 & 28.00 & 22.05 & 17.63 & 100.00 & & & & & $(2.47-2.02)$ & (2.01-1.64) & (1.46-1.20) \\
\hline \multirow{2}{*}{ GERMANY } & 173 & 125 & 127 & 90 & 515 & \multirow{2}{*}{27.00} & \multirow{2}{*}{3} & \multirow{2}{*}{$<0.001$} & \multirow{2}{*}{0.23} & 2.39 & 1.51 & 1.55 \\
\hline & 33.59 & 24.27 & 24.66 & 17.48 & 100.00 & & & & & $(3.08-1.85)$ & $(1.97-1.16)$ & $(1.98-1.21)$ \\
\hline \multirow{2}{*}{ SPAIN } & 159 & 136 & 103 & 83 & 481 & \multirow{2}{*}{28.56} & & & & 2.37 & 1.89 & 1.31 \\
\hline & 33.06 & 28.27 & 21.41 & 17.26 & 100.00 & & 3 & $<0.001$ & 0.24 & $(3.09-1.82)$ & $(2.48-1.44)$ & $(1.69-1.01)$ \\
\hline & 157 & 136 & 145 & 99 & 537 & & & & & 1.83 & 1.50 & 1.64 \\
\hline FRANCE & 29.24 & 25.33 & 27.00 & 18.44 & 100.00 & 13.99 & 3 & 0.003 & 0.16 & $(2.35-1.42)$ & $(1.94-1.16)$ & $(2.07-1.30)$ \\
\hline & 154 & 135 & 111 & 73 & 473 & & & & & 2.65 & 2.19 & 1.68 \\
\hline ITALY & 32.56 & 28.54 & 23.47 & 15.43 & 100.00 & 30.94 & 3 & $<0.001$ & 0.26 & $(3.50-2.00)$ & $(2.91-1.65)$ & $(2.16-1.31)$ \\
\hline & 156 & 115 & 120 & 133 & 524 & & & & & 1.25 & 0.83 & 0.87 \\
\hline ENGLAND & 29.77 & 21.95 & 22.90 & 25.38 & 100.00 & 7.68 & 3 & 0.053 & 0.12 & $(1.57-0.99)$ & $(1.06-0.65)$ & $(1.13-0.68)$ \\
\hline & 152 & 142 & 131 & 96 & 521 & 1270 & 3 & 0003 & 016 & 1.82 & 1.66 & 1.49 \\
\hline PORTUGAL & 29.17 & 27.26 & 25.14 & 18.43 & 100.00 & 13.70 & 3 & 0.003 & 0.16 & $(2.36-1.41)$ & $(2.15-1.28)$ & $(1.89-1.17)$ \\
\hline & 313 & 262 & 195 & 142 & 912 & 7397 & & & & 2.83 & 2.19 & 1.47 \\
\hline ARGENTINA & 34.32 & 28.73 & 21.38 & 15.57 & 100.00 & 73.97 & 3 & $<0.001$ & 0.28 & $(3.46-2.32)$ & (2.68-1.78) & $(1.78-1.23)$ \\
\hline & 253 & 194 & 150 & 117 & 714 & & & & & 2.85 & 1.92 & 1.43 \\
\hline BRAZIL & 35.43 & 27.17 & 21.01 & 16.39 & 100.00 & 58.18 & 3 & $<0.001$ & 0.29 & $(3.55-2.29)$ & $(2.42-1.53)$ & $(1.77-1.16)$ \\
\hline & 137 & 133 & 90 & 80 & 440 & & & & & 1.71 & 1.66 & 1.13 \\
\hline CHILE & 31.14 & 30.23 & 20.45 & 18.18 & 100.00 & 23.26 & 3 & $<0.001$ & 0.23 & $(2.26-1.3)$ & $(2.19-1.26)$ & $(1.47-0.86)$ \\
\hline & 187 & 141 & 147 & 110 & 585 & & & & & 2.31 & 1.58 & 1.45 \\
\hline COLOMBIA & 31.97 & 24.10 & 25.13 & 18.80 & 100.00 & 19.88 & 3 & $<0.001$ & 0.18 & $(2.93-1.82)$ & $(2.02-1.23)$ & $(1.83-1.15)$ \\
\hline & 91 & 107 & 74 & 76 & 348 & & & & & 1.58 & 1.63 & 1.09 \\
\hline ECUADOR & 26.15 & 30.75 & 21.26 & 21.84 & 100.00 & 8.11 & 3 & 0.044 & 0.15 & $(2.14-1.16)$ & $(2.19-1.22)$ & $(1.462-0.81)$ \\
\hline & 117 & 114 & 93 & 74 & 398 & & & & & 1.38 & 1.40 & 1.21 \\
\hline PARAGUAY & 29.40 & 28.64 & 23.37 & 18.59 & 100.00 & 12.15 & 3 & 0.007 & 0.17 & (1.84-1.03) & $(1.87-1.04)$ & $(1.59-0.92)$ \\
\hline
\end{tabular}


As shown the graphical representation of the different odds ratios and their CI (95\%), in the majority of cases the odds ratio values are statistically significant except for the English league in Q1-Q4 (Figure 2), for the Italian league in Q2-Q4 (Figure 3) and for the leagues of Italy, Chile, Ecuador and Paraguay in Q3-Q4 (Figure 4), since in these cases the CI contains the value 1.

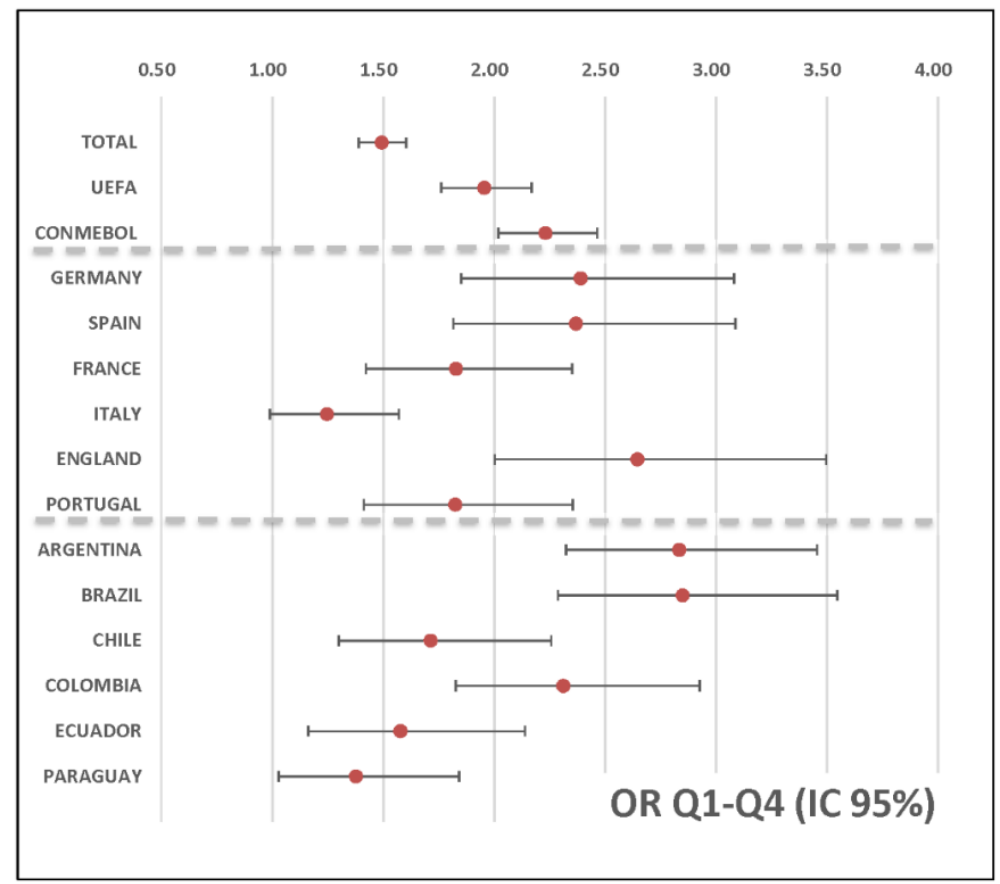

FIGURE 2: Odds ratio (OR) and 95\% confidence interval (CI) comparing first quarter of birth (Q1) and fourth quarter of birth (Q4) of the players according the different categories and leagues. 


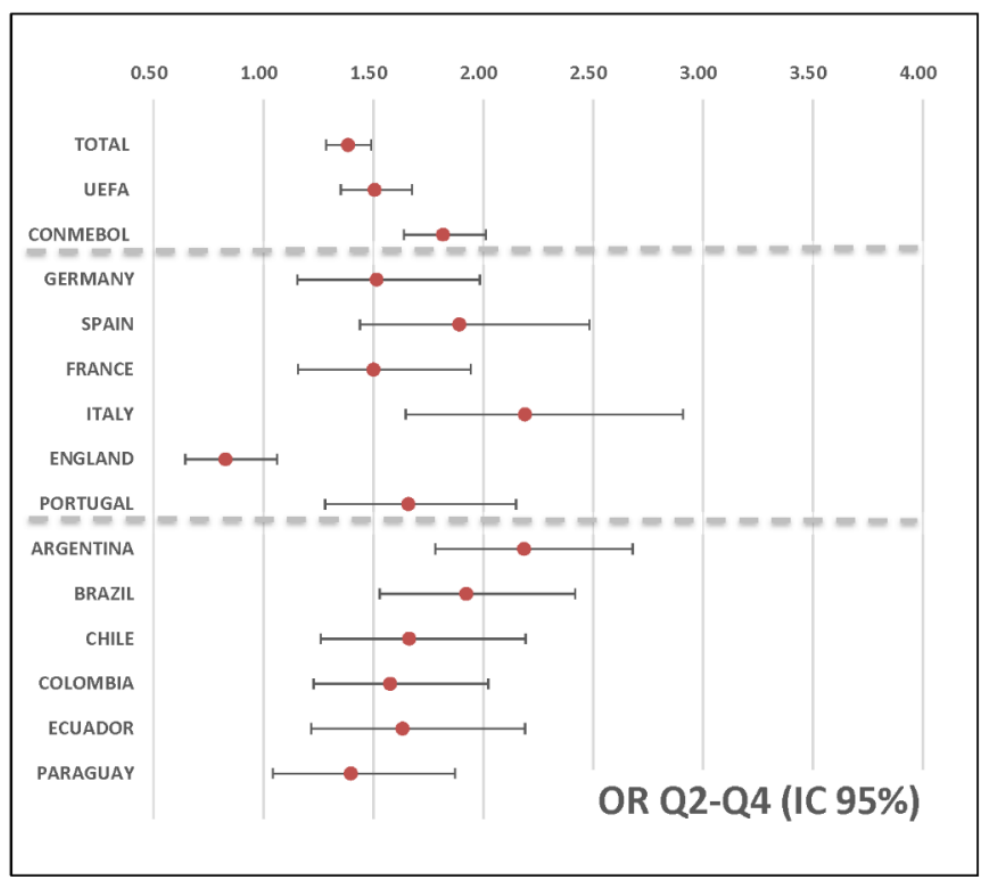

FIGURE 3: Odds ratio (OR) and 95\% confidence interval (CI) comparing first quarter of birth (Q1) and fourth quarter of birth (Q4) of the players according the different categories and leagues. 


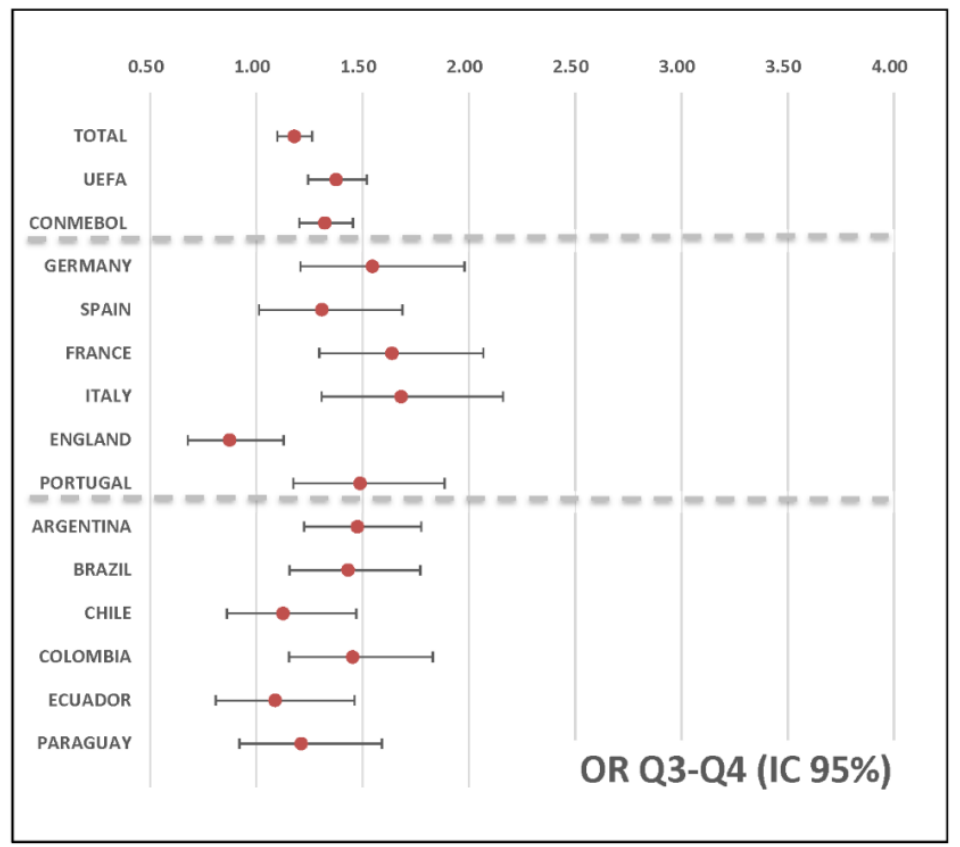

FIGURE 4: Odds ratio (OR) and 95\% confidence interval (CI) comparing third quarter of birth (Q3) and fourth quarter of birth (Q4) of the players according the different categories and leagues.

\section{DISCUSSION}

The aim of the present research was to analyse the dates of birth, in order to examine the effect of relative age on the professional male elite football of two Confederations with a long tradition and sporting success of the FIFA: the Union of European Football Associations (UEFA) and the South American Football Confederation (CONMEBOL), as well as to verify the possible differences and correlations between the RAE and the six best national leagues of these two confederations during the 2016/2017 season.

In our study, there was an over-representation of players born in Q1 (between January and March) and Q2 (between April and June) in both Confederations (UEFA and CONMEBOL), with a greater number born in Q1 (31.17\% in UEFA and 32.32\% in CONMEBOL) and with a significant relative age effect in both. However, a higher odds ratio was estimated by comparing Q1 and Q4 in the CONMEBOL Confederation (2.23) in relation to UEFA (1.95). This may lead us to the idea that, the decision making of coaches in relation to the selection of talents, can be made according to criteria linked to anthropometric, physical and physiological variables, intimately related to the RAE, at the expense of talent. Our study matches with the study of Williams (2010), conducted with U-17 players, showing that the RAE is present in both FIFA 
Confederations studied by us. Although his research found the exception of the African Football Confederation (CAF), where the opposite effect occurs, with an over-representation of players born in Q4. However, some research supports the idea that relative age is not associated with better physical performance or anthropometrics but the maturity status (Carling et al., 2009; Peña-González et al., 2018).

Leagues variable related to the RAE, is a topic of research profusely explored in the field of football. Our study revealed that RAE is present in a significant way in each and every one of the 12 leagues studied, except in the Premier league (England). The leagues that have the greatest effect, analysing the odds ratio, are Italy and Germany (UEFA), and Brazil and Argentina (CONMEBOL). These leagues report an extraordinary number of titles in the European and South American contexts. Padrón-Cabo et al., (2016) study this phenomenon in 14 leagues of different FIFA Confederations (Spain, Germany, Italy, France, Portugal, Holland, Belgium, Ukraine, South Africa, Australia, Mexico and Brazil) and conclude that the RAE is present in all these leagues, except the Premier League (England) and the K-League Classic (South Korea), results that largely coincide with those of our study. Helsen et al. (2012) also found, during the 2010-2011 season, RAE for all professional leagues analysed (England, Germany, Belgium, Netherlands, Spain, France, Italy, Denmark and Sweden), except for the Portuguese league. In turn, Yagüe et al. (2018), studied the RAE in the ten best national leagues of the UEFA Confederation in the $2016 / 2017$ season, identifying that this phenomenon is present in a significant way in all leagues, except in the Eerte Klasse A (Belgium).

Regarding football, different investigations corroborate the RAE, alluding normally to the league of a certain country. In Spain, Prieto et al. (2015) endorse the effect; in Turkey, Mulazimoglu (2014), expose the existence of the RAE in professional teams and elite young players. In other countries, there is also further investigation similar to ours exploring this variable, such as those carried out in Belgium (Helsen et al., 2005; Vaeyens, Philippaerts, y Malina, 2005), in Germany (Augste y Lames, 2011; Cobley et al., 2008), and Australia (Van den Honert, 2012). Research on the RAE in UEFA countries has been abundant, but we find less assiduity to this topic in CONMEBOL leagues, except in Brazil (Cobley et al., 2008; Silva, Palma, Imbiriba, Ribeiro, y Marques Barbosa, 2015). From this country and the Brazilian Football Confederation (CBF), stands out the study by Da Costa, Albuquerque \& Garganta, (2012), with 202951 professional players registered, born between 1921 and 1996. The results showed the presence of the RAE in football players and a progressive increase over the years, mainly after the 1960s, when physical preparation began its boom in football training. 
Based on previously written, it seems that sports agents (coaches and other sports professionals) should know and restrict the effect of the relative age in order to avoid the loss of potential high-performance players which leads us to suggest some modifications in the current processes of talent selection in football players, in order to avoid harming those born in the last months of the year. Nevertheless, we arrange a wide scientific literature that provides us with some corrective measures of the RAE to be applied by different sports agents. Regarding football, the scientific literature has suggested some solutions that could refine the effect studied (Haycraft, Kovalchik, Pyne, Larkin, y Robertson, 2018; Padrón-Cabo et al., 2016; Sedano, Vaeyens, y Redondo, 2015). There follows some of the main RAE's limiting measures. Given the complexity of the question, a first solution could be the presence, during the selective processes, of professionals who would shape a transversal sports' performance team (including coaches, doctors, psychologists, biomechanicals and researchers), in order to understand the football player entirety, not only his physical dimension, but also his technical-tactical and psychological features, in such a way that the selection indicators would be expanded, and the subject's chronological age would not condition the process as seems to be at present. In the line of bio-banding (Cumming, Lloyd, Oliver, Eisenmann, y Malina, 2017), a strategy that intends to group athletes according to attributes related to growth and mature development, instead of using chronological age as a selection criterion. A second option is to increase the number of competition categories, which means a smaller age difference between players belonging to the same category and, therefore, with an undisputed smaller contrast in maturity aspects. As a third proposal, Cobley et al. (2008) suggest that a greater number of football teams would maximise opportunities and reduce both competence and the need for selection, thereby reducing the RAE. Finally, a last measure, even though changes in age policies do not seem to have had the expected results (Haycraft et al., 2018), occasionally change the cut-off dates, so that all footballers, at some point in their sports career, had the opportunity to benefit from competing at a higher relative age.

\section{CONCLUSIONS}

In view of the results of the present study, we can conclude that there is an over-representation of players born in Q1 and Q2, with a significant relative age effect in men's football in the two FIFA Confederations analysed: UEFA and CONMEBOL, with a higher incidence in the latter. Concerning the analysis by leagues, the RAE is significantly present in the six best national leagues of these two confederations in the 2016/2017 season, except in the Premier League (England). According to the odds ratio analysis, the leagues with the greatest effect are Italy and Germany (UEFA) and Brazil and Argentina (CONMEBOL). 
The results obtained in this research have proved that the date of birth is a criterion that is valued, even unconsciously, in the talents' selection in football. These results can be useful for the complex task of selecting players from the lower categories. The presence of RAE means that players are recruited based on physical capacity, anthropometrics and maturity development criteria, with a short-term perspective to achieve immediate sporting success. We advocate for a change of perspective in the selection process, with a long-term perspective, which allows for diverse aspects in the recruitment (psychological, technical-tactical, family and social environment, etc.) and with the main idea that young footballers should be grouped according to their biological development rather than chronological age, to avoid "unfair competition".

\section{REFERENCES}

Albuquerque, M. R., Tavares, V., Lage, G. M., De Paula, J. J., Da Costa, I. T., \& Malloy-Diniz, L. F. (2013). Relative age effect in Olympic Judo athletes: A weight category analysis. Science \& Sports, 28(3), e59-e61. https://doi.org/10.1016/j.scispo.2012.09.004

Augste, C., \& Lames, M. (2011). The relative age effect and success in German elite U-17 soccer teams. Journal of Sports Sciences, 29(9), 983-987. https://doi.org/10.1080/02640414.2011.574719

Barnsley, R. H., Thompson, A., \& Legault, P. (1992). Family planning: Football style. The relative age effect in football. International Review for the Sociology of Sport, 27(1), 77-87.

Bell,. F., Sykes, E. D., \& Vidal, C. (2009). Birthdate Effects: A Review of the Literature from 1990-on: University of Cambridge.

Campbell, T. (2013). In-school ability grouping and the month of birth effect. Preliminary evidence from the Millenium Cohort Study. London: Centre for Longitudinal Studies.

Campos, F. A., Campos, L. C., Pellegrinotti, I. L., \& Gómez, M. A. (2017). The Relative Age Effect in Soccer: an Analysis of the U20 Libertadores Cup. International Journal of Exercise Sciences, 10(8), 1157-1164.

Carling, C., Le Gall, F., Reilly, T., \& Williams, A. M. (2009). Do anthropometric and fitness characteristics vary according to birth date distribution in elite youth academy soccer players?. Scandinavian Journal of Medicine \& Science in Sports, 19(1), 3-9. https://doi.org/10.1111/j.1600-0838.2008.00867.x

Cobley, S. P., Schorer, J., \& Baker, J. (2008). Relative age effects in professional German soccer: A historical analysis. Journal of Sports Sciences, 26(14), 1531-1538. https://doi.org/10.1080/02640410802298250

Cohen, J. (1988). Statistical power analysis for the behaviors science.(2nd). New Jersey: Laurence Erlbaum Associates, Publishers, Hillsdale. 
Costa, I. T. D., Albuquerque, R. M., \& Garganta, J. (2012). Relative age effect in Brazilian soccer players: a historical analysis. International Journal of Performance and Analysis in Sport, 12(3), 563-570. https://doi.org/10.1080/24748668.2012.11868619

Cumming, S. P., Lloyd, R. S., Oliver, J. L., Eisenmann, J. C., \& Malina, R. M. (2017). Bio-banding in sport: applications to competition, talent identification, and strength and conditioning of youth athletes. Strength \& Conditioning Journal, 39(2), 34-47. https://doi.org/10.1519/ssc.0000000000000281

Delorme, N., Boiché, J., \& Raspaud, M. (2010). Relative age effect in elite sports: Methodological bias or real discrimination? Eurpean Journal of Sport Sciences, 10(2), 91-96. https://doi.org/10.1080/17461390903271584

González-Víllora, S., Pastor-Vicedo, J. C., \& Cordente, D. (2015). Relative age effect in UEFA championship soccer players. Journal of Human Kinetics, 47(1), 237-248. https://doi.org/10.1515/hukin-2015-0079

Gutiérrez, D. (2013). Review of relative age effects and potential ways to reduce them in sport and education. Retos: Nuevas tendencias en educación física, deporte y recreación(23), 51-63.

Gutiérrez, D., Vicedo, P., Carlos, J., Gonzalez Villora, S., Jordan, C., \& Ricardo, 0. (2010). The relative age effect in youth soccer players from Spain. Journal of Sports Sciences and Medicine, 9(2), 190-198.

Haycraft, J. A., Kovalchik, S., Pyne, D. B., Larkin, P., \& Robertson, S. (2018). The influence of age-policy changes on the relative age effect across the Australian Rules football talent pathway. Journal of Science and Medicine in Sport, 21(10), 1106-1111. https://doi.org/10.1016/j.jsams.2018.03.008

Helsen, W. F., Baker, J., Michiels, S., Schorer, J., Van Winckel, J., \& Williams, A. M. (2012). The relative age effect in European professional soccer: Did ten years of research make any difference? Journal of Sports Sciences, 30(15), 1665-1671. https://doi.org/10.1080/02640414.2012.721929

Helsen, W. F., Van Winckel, J., \& Williams, A. M. (2005). The relative age effect in youth soccer across Europe. Journal of Sports Sciences , 23(6), 629-636.

Malina, R. M., Bouchard, C., \& Bar-Or, O. (2004). Growth, maturation, and physical activity. Human Kinetics

Mulazimoglu, O. (2014). The relative age effect (RAE) in youth and professional soccer players in Turkey. The Anthropologist, 18(2), 391-398. https://doi.org/10.1080/09720073.2014.11891557

Musch, J., \& Grondin, S. (2001). Unequal competition as an impediment to personal development: A review of the relative age effect in sport. Developmental review, 21(2), 147-167. https://doi.org/10.1006/drev.2000.0516

Padrón-Cabo, A., Rey, E., García-Soidán, J. L., \& Penedo-Jamardo, E. (2016). Large scale analysis of relative age effect on professional soccer players in 
FIFA designated zones. International Journal of Performance and Analysis in Sport, 16(1), 332-346. https://doi.org/10.1080/24748668.2016.11868890 Peeters, T. (2018). Testing the Wisdom of Crowds in the field: Transfermarkt valuations and international soccer results. International Journal of Forecasting, 34(1), 17-29. https://doi.org/10.1016/j.ijforecast.2017.08.002 Peña-González, I., Fernández-Fernández, J., Moya-Ramón, M., \& Cervelló, E. (2018). Relative age effect, biological maturation, and coaches' efficacy expectations in young male soccer players. Research Quarterly for Exercise and Sport, $89(3)$,

373-379.

https://doi.org/10.1080/02701367.2018.1486003

Prieto, A., Pastor, J., Serra, J., \& González, S. (2015). Relative Age Effect in Spanish Football: the 2013/14 Season. Apunts. Educación Física y Deportes, 121, 36-43. doi: 10.5672/apunts.2014-0983.es.(2015/3).121.05

Práxedes, A., Del Villar, F., Gil-Arias, A., Pizarro, D., \& Moreno, A. (2019). Evolution of the relative age effect in spanish young footballers (U8 to U19). A comparative analysis in elite clubs vs. low-level clubs. European Journal of Human Movement, 43, 102-114.

Sedano, S., Vaeyens, R., \& Redondo, J. C. (2015). The relative age effect in Spanish female soccer players. Influence of the competitive level and a playing position. Journal of Human Kinetics, 46(1), 129-137. https://doi.org/10.1515/hukin-2015-0041

Silva, C. J., Palma, A., Imbiriba, L. A., Ribeiro, M., \& Marques Barbosa, M. A. (2015). Relationship between relative age effect and physical characteristics of young soccer players. Cultura, Ciencia y Deporte, 10(30), 227-233. https://doi.org/10.12800/ccd.v10i30.591

Szumilas, M. (2010). Explaining odds ratios. Journal of the Canadian Academy of Child and Adolescent Psychiatry, 19(3), 227.

Torres-Unda, J., Zarrazquin, I., Gil, J., Ruiz, F., Irazusta, A., Kortajarena, M., \& Irazusta, J. (2013). Anthropometric, physiological and maturational characteristics in selected elite and non-elite male adolescent basketball players. Journal of Sports Sciences, 31(2), 196-203. https://doi.org/10.1080/02640414.2012.725133

Vaeyens, R., Philippaerts, R. M., \& Malina, R. M. (2005). The relative age effect in soccer: A match-related perspective. Journal of Sports Sciences, 23(7), 747756. https://doi.org/10.1080/02640410400022052

Van den Honert, R. (2012). Evidence of the relative age effect in football in Australia. Journal of Sports Sciences, 30(13), 1365-1374. https://doi.org/10.1080/02640414.2012.707329

Williams, J. H. (2010). Relative age effect in youth soccer: analysis of the FIFA U17 World Cup competition. Scandinavian Journal of Medicine and Science in Sports, 20(3), 502-508. 
Yagüe, J. M., de la Rubia, A., Sánchez-Molina, J., Maroto-Izquierdo, S., \& Molinero, 0. (2018). The Relative Age Effect in the 10 Best Leagues of Male Professional Football of the Union of European Football Associations (UEFA). Journal of Sports Science and Medicine, 17(3), 409. 